\title{
RESEARCH
}

\section{Intravenously administered vitamin C as cancer therapy: three cases}

\author{
Sebastian J. Padayatty, Hugh D. Riordan, Stephen M. Hewitt, Arie Katz, L. John Hoffer, Mark Levine
}

$\infty$

See related article page 956

\section{ABSTRACT}

Early clinical studies showed that high-dose vitamin C, given by intravenous and oral routes, may improve symptoms and prolong life in patients with terminal cancer. Double-blind placebo-controlled studies of oral vitamin C therapy showed no benefit. Recent evidence shows that oral administration of the maximum tolerated dose of vitamin C $(18 \mathrm{~g} / \mathrm{d})$ produces peak plasma concentrations of only $220 \mu \mathrm{mol} / \mathrm{L}$, whereas intravenous administration of the same dose produces plasma concentrations about 25 -fold higher. Larger doses $(50-100 \mathrm{~g}$ ) given intravenously may result in plasma concentrations of about $14000 \mu \mathrm{mol} / \mathrm{L}$. At concentrations above $1000 \mu \mathrm{mol} / \mathrm{L}$, vitamin $C$ is toxic to some cancer cells but not to normal cells in vitro. We found 3 well-documented cases of advanced cancers, confirmed by histopathologic review, where patients had unexpectedly long survival times after receiving high-dose intravenous vitamin $C$ therapy. We examined clinical details of each case in accordance with National Cancer Institute ( $\mathrm{NCl}$ ) Best Case Series guidelines. Tumour pathology was verified by pathologists at the $\mathrm{NCl}$ who were unaware of diagnosis or treatment. In light of recent clinical pharmacokinetic findings and in vitro evidence of anti-tumour mechanisms, these case reports indicate that the role of high-dose intravenous vitamin C therapy in cancer treatment should be reassessed.

CMAJ 2006;174(7):937-42

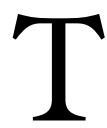
hirty years ago Cameron, Campbell and Pauling reported beneficial effects of high-dose vitamin $\mathrm{C}$ (ascorbic acid) therapy for patients with terminal cancer. ${ }^{1-4}$ Subsequent double-blind, randomized clinical trials at the Mayo Clinic failed to show any benefit,, ${ }^{5,6}$ and the role of vitamin $\mathrm{C}$ in cancer treatment was discarded by mainstream oncologists. ${ }^{7,8}$ Vitamin $\mathrm{C}$ continues, however, to be used as an alternative cancer therapy. ${ }^{9,10}$

A key distinction between conventional, science-based medicine and alternative therapy is the presence or absence of scientific plausibility. ${ }^{11}$ In conventional medicine, the efficacy of treatment is proven by properly conducted clinical trials. Many treatments are still used if there is moderately good, albeit inconclusive evidence of efficacy ("clinical plausibility"), especially when treatment rationale agrees with biologic facts (conferring "biological plausibility"). ${ }^{11}$ Vitamin C is an alternative cancer therapy because the results obtained in original studies that suggested clinical benefit were not confirmed by controlled clinical trials, and the notion that high-dose vitamin $\mathrm{C}$ was selectively toxic to cancer cells was biologically implausible.

New information is available pertaining to biological plausibility. Although similar doses of vitamin $\mathrm{C}$ were used in the Cameron-Pauling and Mayo Clinic studies, the Cameron-Pauling studies combined intravenous and oral administration whereas the Mayo Clinic studies used only oral administration. ${ }^{1,2,12-14}$ Recent pharmacokinetics modeling ${ }^{15}$ indicates that with oral administration, even very large and frequent doses of vitamin $\mathrm{C}$ will increase plasma concentrations only modestly, from $70 \mu \mathrm{mol} / \mathrm{L}$ to a maximum of $220 \mu \mathrm{mol} / \mathrm{L}$, whereas intravenous administration raises plasma concentrations as high as $14000 \mu \mathrm{mol} / \mathrm{L}$. Concentrations of rooo$5000 \mu \mathrm{mol} / \mathrm{L}$ are selectively cytotoxic to tumour cells in vitro, ${ }^{16-20}$ and emerging evidence indicates that ascorbic acid at concentrations achieved only by the intravenous route may function as a pro-drug for hydrogen peroxide delivery to tissues. ${ }^{20}$ The in vitro biologic evidence and clinical pharmacokinetics data confer biological plausibility to the notion that vitamin $C$ could affect cancer biology and may explain in part the negative results of the Mayo Clinic trials. ${ }^{13,15,21,22}$ Thus, sufficient evidence has accumulated, not to use vitamin $\mathrm{C}$ as cancer treatment, but to further explore the therapeutic concept. One way to increase the clinical plausibility of alternative cancer therapies is rigorous, well-documented case reporting, as laid out in the US National Cancer Institute (NCI) Best Case Series guidelines (http://www3.cancer.gov/occam/bestcase.html). ${ }^{23,24}$ Such case series might identify alternative therapies that merit further investigation. ${ }^{23,24}$

Case reports of apparent responses by malignant disease to intravenous vitamin $\mathrm{C}$ therapy have appeared, ${ }^{25-30}$ including those of 2 of the 3 patients presented below. ${ }^{25,26}$ However, they were reported without sufficient detail or with incomplete follow-up for evaluation and without conforming to NCI Best Case Series guidelines. They also lacked objective pathologic confirmation, which is a pillar of NCI guidelines. In this article, we use NCI Best Case Series guidelines to report 3 cases of patients with usually progressive malignant 
disease who received intravenous vitamin $\mathrm{C}$ therapy as their only significant cancer therapy and whose clinical courses were unusually favourable. Original diagnostic material obtained before treatment with vitamin $\mathrm{C}$ was reviewed by pathologists at the National Institutes of Health (NIH) who were unaware of the diagnoses and treatments.

\section{Patient 1}

This case was previously reported but without long-term follow-up, without detail, and with no independent pathologic confirmation. ${ }^{25,26}$ A 5I-year-old woman was found in August I995 to have a tumour involving her left kidney. At nephrectomy in September 1995 this was shown to be a renal cell carcinoma $9 \mathrm{~cm}$ in diameter with thrombus extending into the renal vein. Chest radiography results were normal, and there was no evidence of metastatic disease on CT scan of the chest and abdomen. In March I996 a CT scan of the chest indicated

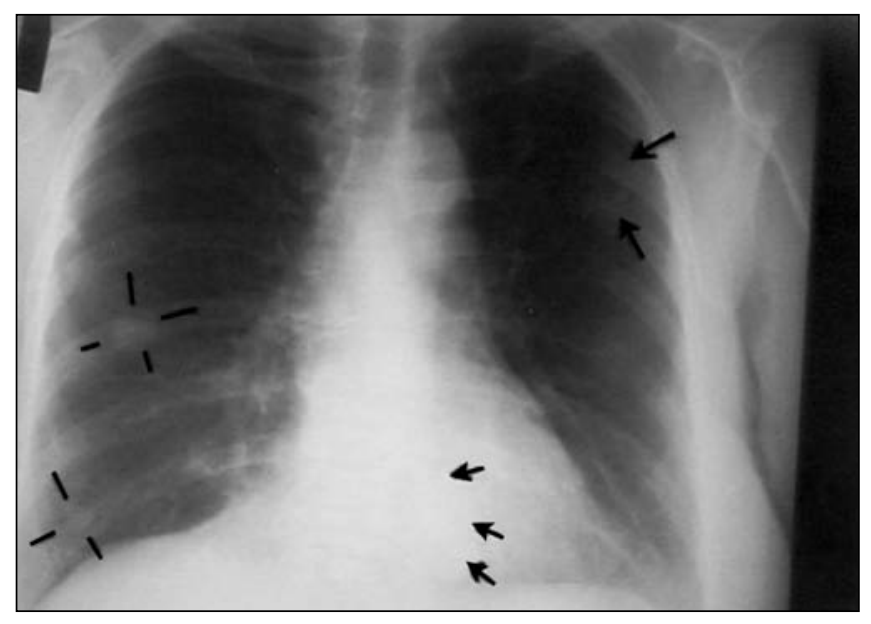

Fig. 1: Chest radiography, November 1996, about 1 month after intravenous vitamin $C$ therapy was started. Cannonball lesions are evident in both lung fields, as indicated by the arrows and lines.

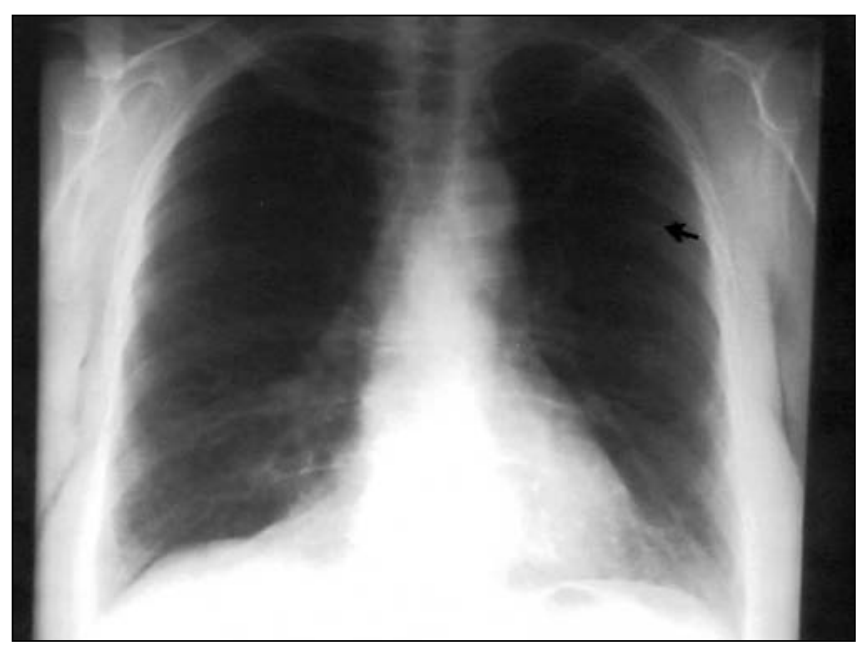

Fig. 2: Chest radiography, June 1997, showing regression of the lesions; the arrow indicates one residual abnormality. several new, small, rounded and well-defined soft tissue masses no larger than $5 \mathrm{~mm}$ in diameter; they were judged consistent with metastatic cancer. By November 1996 chest radiography revealed multiple cannonball lesions (Fig. I).

The patient declined conventional cancer treatment and instead chose to receive high-dose vitamin $\mathrm{C}$ administered intravenously at a dosage of $65 \mathrm{~g}$ twice per week starting in October 1996 and continuing for Io months. She also used other alternative therapies: thymus protein extract, $\mathrm{N}$-acetylcysteine, niacinamide and whole thyroid extract (Table I). In June 1997 chest radiography results were normal except for one remaining abnormality in the left lung field, possibly a pulmonary scar (Fig. 2).

In October $200 \mathrm{I}$ a new mass $3.5 \mathrm{~cm}$ in diameter in the anterior right lung was detected on radiography. A transthoracic biopsy revealed small-cell carcinoma of the lung. The patient opted for intravenous vitamin $\mathrm{C}$ injections. The lung mass remained constant in size in radiograpy taken in May and $\mathrm{Au}-$ gust 2002 but had increased to $4 \mathrm{~cm}$ in views taken in October 2002. In early November hyponatremia developed. Two weeks later the patient was admitted to hospital with abdominal distension and constipation. Barium studies revealed slow transit but no intestinal obstruction. Results of a CT scan of the abdomen were normal. She died shortly afterward, and no autopsy was performed. Histopathologic review of the primary renal tumour at the NIH confirmed the diagnosis of clear-cell renal carcinoma, type, nuclear grade III/IV, with the largest diameter measuring $6.5 \mathrm{~cm}$. The tumour involved the renal vein and hilar perinephric fat. Pathologic review of the lung tumour biopsy specimen of October 200I was not conducted at the NIH. Local pathologists diagnosed this specimen as indicating small-cell lung cancer and not recurrent metastatic renal cell carcinoma.

This case describes the regression of pulmonary metastatic renal cancer in a patient receiving high-dose intravenous vitamin C therapy. According to the NCI Best Case Series guidelines, the credibility of this case would be increased by biopsy proof that the multiple slowly growing bilateral cannonball lung nodules in this patient with known renal cell carcinoma were actually malignant. However, in this case, the clinical characteristics and evolution of the pulmonary lesions, in the absence of bacterial infection or other systemic disease, make any other diagnosis unlikely. The clinician attending the patient deemed a confirmatory biopsy to be unnecessary and inappropriate in this setting. A plausible alternative explanation to the conclusion that this patient's metastatic renal cell cancer responded to intravenous vitamin C therapy is that the tumours spontaneously regressed. Spontaneous regression has been reported in renal cell cancer, but it is rare, occurring in fewer than $\%$ of cases and typically after nephrectomy, radiation to the primary tumour or primary tumour embolization. ${ }^{31,32}$ Here, metastatic disease appeared several months after nephrectomy, rather than regressing in response to it. As well, the primary cancer was nuclear grade III/IV and involved the renal vein, factors associated with a highly unfavourable prognosis. ${ }^{31}$

Of note, more than 4 years after stopping intravenous vitamin C therapy and with the renal cell cancer in complete re- 
mission, primary small-cell lung cancer was diagnosed in this patient, who was a long-standing cigarette smoker. The second cancer did not respond to high-dose vitamin C therapy. From the clinical history it appears the tumour remained a constant size for many months and likely slowly progressed until her death about a year after diagnosis despite the resumption of intravenous vitamin $C$ therapy.

\section{Patient 2}

A 49-year-old man presented to his physician in 1996 with hematuria and was found at cystoscopy to have a primary bladder tumour with multiple satellite tumours extending $2-3 \mathrm{~cm}$ around it. Transurethral resection of the primary tumour and its surrounding tumour satellites was carried out until apparently normal muscle was reached and the tumour base was fulgurated. The patient declined systemic or intravesical chemotherapy or radiotherapy and instead chose intravenous vitamin $\mathrm{C}$ treatment. He received $30 \mathrm{~g}$ of vitamin $\mathrm{C}$ twice per week for 3 months, followed by $30 \mathrm{~g}$ once every $\mathrm{I}-2$ months for 4 years, interspersed with periods of $\mathrm{I}-2$ months during which he had more frequent infusions. Histopathologic review at the $\mathrm{NIH}$ revealed a grade $3 / 3$ papillary transitional cell carcinoma invading the muscularis propria. Now, 9 years after diagnosis, the patient is in good health with no symptoms of recurrence or metastasis. The patient used the following supplements: botanical extract, chondroitin sulfate, chromium picolinate, flax oil, glucosamine sulfate, $\alpha$-lipoic acid, Lactobacillus acidophilus and L. rhamnosus and selenium (Table 2).

Complete or partial bladder removal is the standard treatment for stage T2 (muscle invasive) bladder cancer, since the presence of muscle invasion appears to be the best predictor of aggressive behaviour. When treated only locally, as in this case, invasive transitional cell bladder cancer almost invariably develops into clinically apparent local or metastatic disease within a short period. ${ }^{33-35}$ There are reports of transurethral tumour resection being offered as the sole initial therapy in carefully selected patients with $\mathrm{T} 2$ disease. In one report $20 \%$ of patients with muscle invasive bladder cancer treated only with transurethral resection remained free of recurrent disease after $3-7$ years of follow-up. ${ }^{36}$ However, such minimal therapy is considered an option only when the cancer is solitary, well defined and completely excised as documented by pathologic evaluation, ${ }^{37}$ whereas this patient presented with multiple tumours and associated muscle invasion.

Table 1: Supplementary medication taken concurrently with intravenous vitamin $\mathrm{C}$ therapy by Patient 1

\begin{tabular}{ll}
\hline Start date & \multicolumn{1}{c}{ Medication and dosage } \\
\hline $10-10-96$ & NSC-24 (beta glucan) 1 capsule twice daily \\
\hline $10-10-96$ & N-acetylcysteine $500 \mathrm{mg} 3$ times daily \\
\hline $8-26-97$ & $\begin{array}{l}\text { Niacinamide } 500 \mathrm{mg} 2 \text { capsules taken } 30 \mathrm{~min} \\
\text { before intravenous vitamin C therapy, } \\
\text { increasing to } 4 \text { capsules and then } 6 \text { capsules } \\
\text { (3000 mg) before vitamin C infusion }\end{array}$ \\
\hline $6-15-98$ & Whole thyroid extract 30 mg once daily \\
\hline
\end{tabular}

\section{Patient 3}

This case was previously reported but without detail and without independent pathologic confirmation. ${ }^{26,30}$ A 66-yearold woman was found in January 1995 to have a large left paraspinal mass medial to the iliopsoas muscle at the $\mathrm{L}_{4}-5$ level. On imaging the mass measured $3.5-7 \mathrm{~cm}$ transversely and II $\mathrm{cm}$ in the craniocaudal direction, with evidence of extension into the posterior paraspinal muscle and bone invasion. Chest radiography results were normal. An open biopsy specimen was diagnostic of a diffuse large B-cell lymphoma. The patient's oncologist recommended local radiation therapy and chemotherapy. Although she agreed to a 5week course of local radiation therapy, the patient refused chemotherapy, electing instead to receive vitamin C intravenously. She received $15 \mathrm{~g}$ of vitamin $\mathrm{C}$ twice per week for about 2 months, $15 \mathrm{~g}$ once to twice per week for about 7 months, and then $15 \mathrm{~g}$ once every 2-3 months for about I year. This began in mid-January 1995 concurrently with the radiation therapy, which was given as AP/PA parallel opposed I8 MEV X-rays and between I-I8 and 2-28-95, 5040 Centi Gray in 28 fractions delivered to the mid-plane of the body with 3:2 loading from the back. At this time a left axillary lymph node $\mathrm{I} \mathrm{cm}$ in diameter and a right axillary lymph node $\mathrm{I} .5 \mathrm{~cm}$ in diameter were palpable.

Two weeks later, in early February 1995, the right and left axillary lymph nodes remained palpable and a new left cervi-

Table 2: Supplementary medication taken concurrently with intravenous vitamin C therapy by Patient 2

\begin{tabular}{|c|c|}
\hline Start date & Medication and dosage \\
\hline $12-12-96$ & $\begin{array}{l}\text { Vermox (mebendazole) } 100 \mathrm{mg} 1 \text { tablet once } \\
\text { daily for } 3 \mathrm{~d} \text {, repeated after } 1 \mathrm{wk}\end{array}$ \\
\hline $12-12-96$ & $\begin{array}{l}\text { After completion of Vermox, Parex (botanical } \\
\text { supplement) } 2 \text { tablets } 3 \text { times daily }\end{array}$ \\
\hline $12-19-96$ & $\begin{array}{l}\text { Emergen C (vitamin and mineral supplement } \\
\text { with } 1 \mathrm{~g} \text { vitamin C) } 1 \text { packet in } 6 \text { oz water twice } \\
\text { daily }\end{array}$ \\
\hline $12-19-96$ & Flax oil capsules 1 with each meal \\
\hline $3-5-97$ & $\alpha$-Lipoic acid $100 \mathrm{mg}$ daily \\
\hline 4-9-97 & $\begin{array}{l}\text { Vital Dophilus (Lactobacillus acidophilus, } L \text {. } \\
\text { rhamnosus) } 1 \text { scoop daily }\end{array}$ \\
\hline 4-9-97 & Glutathione 1 tablet with each meal \\
\hline $6-30-97$ & Zinc Boost (zinc) 1 tablet twice daily \\
\hline $11-17-97$ & $\begin{array}{l}\text { Glucosamine sulfate } 500 \mathrm{mg} 4 \text { times daily; } \\
\text { chondroitin sulfate } 500 \mathrm{mg} \text { twice daily }\end{array}$ \\
\hline $11-17-97$ & Calf liver every couple of weeks \\
\hline $12-22-98$ & $\alpha$-Lipoic acid 300 mg daily \\
\hline $12-22-98$ & Chromium picolinate $200 \mathrm{mcg}$ daily \\
\hline $12-22-98$ & Selenium up to $400 \mathrm{mcg}$ daily, on and off \\
\hline $9-04-00$ & $\begin{array}{l}\text { Magnesium } 1 \mathrm{~mL} \text { with intravenous vitamin } \mathrm{C} \\
\text { therapy }\end{array}$ \\
\hline $10-27-00$ & $\begin{array}{l}\text { IVC-Max (vitamin K, niacinamide, biotin, } \\
\text { selenium, } \alpha \text {-lipoic acid, quercetin, grape seed } \\
\text { extract) } 1 \text { capsule twice daily }\end{array}$ \\
\hline
\end{tabular}


cal lymph node $\mathrm{I} \mathrm{cm}$ in diameter and a new left supraclavicular lymph node larger than I $\mathrm{cm}$ were apparent on physical examination. Intravenous vitamin $C$ therapy continued. Three weeks later the supraclavicular and cervical lymph nodes were no longer palpable, the left axillary node had disappeared, and the right axillary node had decreased in size to less than I $\mathrm{cm}$. After a further 3 weeks, in mid-March 1995 , there was no lymphadenopathy in the neck and no palpable axillary lymphadenopathy. In late April 1995 a new left cervical lymph node was detected, and histopathologic review identified a biopsy specimen as identical to the original tumour. The patient once again refused chemotherapy and continued her program of intravenous vitamin C injections. Two months later, in June 1995 , there was marked left supraclavicular lymphadenopthy $3 \mathrm{~cm}$ in size, with shotty right axillary nodes but no adenopathy in the left axilla. Four months later, in October 1995, a single right submandibular node was palpable, but the supraclavicular and all other areas, including the axillas, had no palpable lymph nodes. In May 1996 a left anterior cervical node $1.5 \mathrm{~cm}$ in size was present, but there was no other adenopathy. Intravenous vitamin $C$ therapy continued through late December 1996, at which time the patient was in normal health and had no clinical sign of lymphoma. The patient remains in normal health ro years after the diagnosis of diffuse large B-cell lymphoma, never having received chemotherapy. The patient used additional products: $\beta$ carotene, bioflavonoids, chondroitin sulfate, coenzyme $\mathrm{Q}_{10}$,

Table 3: Supplementary medication taken concurrently with intravenous vitamin C therapy by Patient 3

\begin{tabular}{|c|c|}
\hline Start date & Medication and dosage \\
\hline $1-13-95$ & $\begin{array}{l}\text { Coenzyme } Q_{10} \text { (ubiquinone) } 200 \mathrm{mg} \text { daily for } 1 \\
\text { wk, followed by } 400 \mathrm{mg} \text { daily }\end{array}$ \\
\hline $1-13-95$ & $\begin{array}{l}\text { Magnesium } 1 \mathrm{~mL} \text { with intravenous vitamin } \mathrm{C} \\
\text { therapy }\end{array}$ \\
\hline $10-19-95$ & $\beta$-carotene 25000 IU 4 times daily \\
\hline $1-27-95$ & $\begin{array}{l}\text { Parasidal (Sweet wormwood whole plant } \\
\text { extract, ginger root and rhizome extract, sour } \\
\text { plum fruit extract) } 1 \text { tablet } 3 \text { times daily }\end{array}$ \\
\hline $1-27-95$ & Vitamin B supplement, intake doubled \\
\hline $1-27-95$ & Dehydroepiandrosterone $25 \mathrm{mg}$ daily \\
\hline $1-27-95$ & OsteoPrime 1 tablet 4 times daily \\
\hline $5-15-95$ & $\begin{array}{l}\text { Vitamin C with bioflavonoids } 1000 \mathrm{mg} \text { daily, } \\
\text { increased by } 1-2 \mathrm{gm} / \mathrm{d} \text { each wk }\end{array}$ \\
\hline $6-08-95$ & $\mathrm{~N}$-acetylcysteine $500 \mathrm{mg}$ twice daily \\
\hline $3-18-96$ & $\begin{array}{l}\text { Magnesium } 1 \mathrm{~mL} \text { with intravenous vitamin } \mathrm{C} \\
\text { therapy }\end{array}$ \\
\hline $4-01-96$ & $\begin{array}{l}\text { Pepto Bismol (bismuth) } 2 \text { tablets } 4 \text { times daily } \\
\text { for } 2 \text { wk }\end{array}$ \\
\hline $4-28-96$ & $\begin{array}{l}\text { Parex (botanical supplement) } 2 \text { capsules } 2-3 \\
\text { times daily }\end{array}$ \\
\hline $12-24-96$ & $\begin{array}{l}\text { Magnesium } 1 \mathrm{~mL} \text { with intravenous vitamin } \mathrm{C} \\
\text { therapy }\end{array}$ \\
\hline $9-23-97$ & Chondroitin sulfate $500 \mathrm{mg} 3$ times daily \\
\hline $9-23-97$ & Glucosamine sulfate $500 \mathrm{mg} 4$ times daily \\
\hline
\end{tabular}

dehydroepiandrosterone, a multiple vitamin supplement, Nacetylcysteine, a botanical supplement and bismuth tablets (Table 3). Histopathologic examination of the original paraspinal mass at the NIH confirmed a diffuse large B-cell lymphoma at stage III, with a brisk mitotic rate.

Patients with untreated stage III diffuse B-cell lymphoma have a dismal prognosis. This case, like the preceding one, is unusual in that the patient refused chemotherapy, which might have produced a long-term remission. It appears, nonetheless, that a cure occurred in connection with intravenous vitamin $\mathrm{C}$ infusions.

\section{Discussion}

These cases were analyzed in accordance with the NCI's Best Case Series process, which reports and interprets apparent responses to alternative therapies. ${ }^{23,24}$ Apart from its implications regarding vitamin $\mathrm{C}$, this article illustrates the use of the Best Case Series approach in assessing the clinical plausibility of novel therapies. None of these case histories provides definitive proof that intravenous vitamin $\mathrm{C}$ therapy was responsible for the patient's unusually favourable clinical course. It is often difficult to prove definitively that a given treatment is responsible for a specific clinical outcome. When the treatment is unorthodox, alternative explanations, even if highly unlikely, tend to be preferred. ${ }^{38,39}$ However, although they do not provide grounds for advocating intravenous vitamin $C$ therapy as a cancer treatment, these cases increase the clinical plausibility of the notion that vitamin C administered intravenously might have effects on cancer under certain circumstances.

The overall plausibility of ascorbic acid administered intravenously as a cancer therapy is enhanced by recent insights into clinical pharmacokinetics and in vitro cancer-specific cytotoxicity of vitamin C. ${ }^{15-20}$ Pharmacokinetics data show that orally administered vitamin $\mathrm{C}$ results in tightly controlled plasma and cell concentrations. Subjects consuming 200-300 mg per day of vitamin C in 5 or more daily servings of fruits and vegetables have fasting steady state plasma concentrations of about $70-80 \mu \mathrm{mol} / \mathrm{L}{ }^{40,41}$ Even with maximally tolerated oral doses of $3 \mathrm{~g}$ every 4 hours, peak plasma concentrations are estimated to not exceed $220 \mu \mathrm{mol} / \mathrm{L} .{ }^{15}$ Intravenous administration of vitamin $\mathrm{C}$ bypasses tight control for several hours, until homeostasis is restored by renal excretion. Depending on the dose and infusion rate, peak plasma concentrations obtained intravenously are estimated to reach I4 $000 \mu \mathrm{mol} / \mathrm{L}$, and concentrations above $2000 \mu \mathrm{mol} / \mathrm{L}$ may persist for several hours. Emerging in vitro data show that extracellular ascorbic acid selectively kills some cancer but no normal cells by generating hydrogen peroxide. ${ }^{20}$ Death is mediated exclusively by extracellular ascorbate, at pharmacologic concentrations that can be achieved only by intravenous administration. Vitamin C may serve as a pro-drug for hydrogen peroxide delivery to extravascular tissues, but without the presence of hydrogen peroxide in blood. These data are consistent with clinical pharmacokinetics of vitamin C administered intravenously. ${ }^{15}$ Of note, only a minority of cancer patients reported by Cameron and colleagues responded to 
intravenous and oral vitamin C therapy,${ }^{1-4}$ and not all cancer cells were killed by ascorbic acid in vitro. ${ }^{20}$ Further basic investigation of pharmacologic vitamin $\mathrm{C}$ concentrations in mediating cell death will facilitate discovery of the mechanisms responsible for sensitivity and resistance in vitro and in vivo. On the basis of emerging clinical and in vitro data, earlyphase clinical trials of intravenous vitamin $\mathrm{C}$ therapy alone and in combination with conventional chemotherapy are currently in the planning and execution phase, including a formal phase I trial in progress at McGill University. ${ }^{42-44}$

The cases reported here do not prove that vitamin $\mathrm{C}$ induced the favourable outcomes observed. These patients received other alternative medicine therapies. Spontaneous remission of some tumours may occur rarely, although the 3 cancers reported here are dissimilar. Accretion of more cases meeting NCI Best Case Series guidelines may indicate whether vitamin $\mathrm{C}$ or other factors contribute to such remissions.

It is likely that high vitamin $\mathrm{C}$ intakes have low toxicity, except under certain conditions. ${ }^{45,46}$ Intravascular hemolysis was reported after massive vitamin $\mathrm{C}$ administration in people with glucose-6-phosphate dehydrogenase deficiency. ${ }^{46}$ Administration of high-dose vitamin C to patients with systemic iron overload may increase iron absorption and represents a contraindication. ${ }^{46,47}$ Ascorbic acid is metabolized to oxalate, and 2 cases of acute oxalate nephropathy were reported in patients with pre-existing renal insufficiency given massive intravenous doses of vitamin C. ${ }^{48,49}$ Therefore, patients with renal insufficiency or renal failure, or who are undergoing dialysis, should not receive high doses of vitamin C. ${ }^{46}$ It is controversial whether high-dose vitamin C use is associated with oxalate kidney stones, and patients with hyperoxaluria or a prior history of oxalate kidney stones have a relative contraindication to high-dose vitamin C. ${ }^{46}$ Rare cases of acute tumour hemorrhage and necrosis were reported in patients with advanced cancer within a few days of starting high-dose intravenous vitamin C therapy, although this was not independently verified by pathologic review. ${ }^{1,50}$ Although tumour hemorrhage suggests an anticancer potential for ascorbate, there is the potential for risk to some patients.

The cases reported here are of tumours confirmed by histopathologic examination to have poor prognosis but that instead had long clinical remissions. Most previous case reports lacked independent pathologic confirmation of the tumour and did not follow the NCI Best Case Series guidelines, which makes their interpretation difficult. Recent findings show that only high-dose intravenous, but not oral, vitamin $C$ therapy results in very high plasma vitamin $\mathrm{C}$ concentrations (e.g., I4 $000 \mu \mathrm{mol} / \mathrm{L}$ ). At these concentrations, the vitamin is toxic to some cancer cells, possibly because at these concentrations the vitamin is a pro-drug for hydrogen peroxide formation in extracellular fluid. Accumulated data confer some degree of biological and clinical plausibility to the notion that high-dose intravenous vitamin $\mathrm{C}$ therapy may have anti-tumour effects in certain cancers. When all available data are considered, further clinical study as to safety and efficacy of intravenous vitamin $\mathrm{C}$ is warranted.
This article has been peer reviewed.

From the Molecular and Clinical Nutrition Section, Digestive Diseases Branch, National Institute of Diabetes and Digestive and Kidney Diseases (Padayatty, Katz, Levine), and the Laboratory of Pathology, Centers for Cancer Research, National Cancer Institute (Hewitt), National Institutes of Health, Bethesda, Md.; Lady Davis Institute for Medical Research (Hoffer), McGill University, Montréal, Que.; Bio-Communications Research Institute (Riordan) (deceased), Wichita, Kan.

Competing interests: None declared.

Contributors: Sebastian Padayatty, Arie Katz and Mark Levine wrote the first draft, Hugh Riordan contributed to data acquisition, Stephen Hewitt conducted pathology reviews and John Hoffer revised this article. All of the authors contributed to the conception, design and critical review of the paper. All of the authors approved the final version of the paper, excepting Hugh Riordan. Hugh Riordan died before the final version was accepted but had reviewed and approved an earlier version of the paper.

Acknowledgements: The writing of this paper was supported in part by the Intramural Research Program of the National Institute of Diabetes and Digestive and Kidney Diseases, National Institutes of Health (Zor DK 54506).

Hugh D. Riordan died suddenly during the final preparation of this article. We dedicate it to his memory.

\section{REFERENCES}

I. Cameron E, Campbell A. The orthomolecular treatment of cancer. II. Clinical trial of high-dose ascorbic acid supplements in advanced human cancer. Chem Biol Interact $\mathrm{I} 974 ; 9: 285-3 \mathrm{I} 5$.

2. Cameron E, Campbell A, Jack T. The orthomolecular treatment of cancer. III. Reticulum cell sarcoma: double complete regression induced by high-dose ascorbic acid therapy. Chem Biol Interact I $975 ; 11: 387-93$

3. Cameron E, Pauling L. Supplemental ascorbate in the supportive treatment of cancer: prolongation of survival times in terminal human cancer. Proc Natl Acad Sci U $S A$ I976;73:3685-9.

4. Cameron E, Pauling L. Supplemental ascorbate in the supportive treatment of cancer: reevaluation of prolongation of survival times in terminal human cancer. Proc Natl Acad Sci U S A 1978;75:4538-42.

5. Creagan ET, Moertel CG, O'Fallon JR, et al. Failure of high-dose vitamin C (ascorbic acid) therapy to benefit patients with advanced cancer. A controlled trial. $N$ Engl JMed 1979;301:687-90.

6. Moertel CG, Fleming TR, Creagan ET, et al. High-dose vitamin C versus placebo in the treatment of patients with advanced cancer who have had no prior chemotherapy. A randomized double-blind comparison. N Engl J Med I985;312:137-4I.

7. Wittes RE. Vitamin C and cancer. NEngl J Med 1985;312:178-9.

8. Golde DW. Vitamin C in cancer. Integr Cancer Ther 2003;2:158-9.

9. Bernstein BJ, Grasso T. Prevalence of complementary and alternative medicine use in cancer patients. J ClinOncol 200I;15:1267-72.

Io. Cassileth BR, Deng G. Complementary and alternative therapies for cancer. Oncologist 2004;9:80-9.

II. Hoffer LJ. Complementary or alternative medicine: the need for plausibility. CMA 2003; $168: 180-2$.

I2. Cameron E. Protocol for the use of vitamin $\mathrm{C}$ in the treatment of cancer. Med Hypotheses I991;36:190-4.

13. Padayatty SJ, Levine M. Reevaluation of ascorbate in cancer treatment: emerging evidence, open minds and serendipity. J Am Coll Nutr 2000;19:423-5.

I4. Padayatty SJ, Levine M. New insights into the physiology and pharmacology of vitamin C. CMAJ 2001;164:353-5.

I5. Padayatty SJ, Sun H, Wang Y, et al. Vitamin C pharmacokinetics: implications for oral and intravenous use. Ann Intern Med 2004;I40:533-7.

I6. Benade L, Howard T, Burk D. Synergistic killing of Ehrlich ascites carcinoma cells by ascorbate and 3-amino-I, 2,4,-triazole. Oncology 1969;23:33-43.

I7. Bram S, Froussard P, Guichard M, et al. Vitamin C preferential toxicity for malignant melanoma cells. Nature I980;284:629-3I.

I8. Leung PY, Miyashita K, Young M, et al. Cytotoxic effect of ascorbate and its derivatives on cultured malignant and nonmalignant cell lines. Anticancer Res I993;13:475-80.

I9. Casciari JJ, Riordan NH, Schmidt TL, et al. Cytotoxicity of ascorbate, lipoic acid, and other antioxidants in hollow fibre in vitro tumours. BrJ Cancer 2001;84:1544-50.

20. Chen Q, Espey MG, Krishna MC, et al. Pharmacologic ascorbic acid concentrations selectively kill cancer cells: Action as a pro-drug to deliver hydrogen peroxide to tissues. Proc Natl Acad Sci U S A 2005

2I. Padayatty SJ, Levine M. Vitamin C and coronary microcirculation. Circulation 2001;I03:EII7

22. Hoffer LJ. Proof versus plausibility: rules of engagement for the struggle to evaluate alternative cancer therapies. $C M A J$ 200I; $164: 35 \mathrm{I}-3$

23. White JD. Complementary and alternative medicine research: a National Cancer Institute perspective. Semin Oncol 2002;29:546-51. 
24. Nahin RL. Use of the best case series to evaluate complementary and alternative therapies for cancer: a systematic review. Semin Oncol 2002;29:552-62.

25. Riordan HD, Jackson JA, Riordan $\mathrm{NH}$, et al. High-dose intravenous vitamin $\mathrm{C}$ in the treatment of a patient with renal cell carcinoma of the kidney. J Orthomol Med I998;13:72-3.

26. Riordan HD, Riordan NH, Jackson JA, et al. Intravenous vitamin $\mathrm{C}$ as a chemotherapy agent: a report on clinical cases. PR Health Sci J 2004;23:115-8.

27. Riordan HD, Jackson JA, Schultz M. Case study: high-dose intravenous vitamin C in the treatment of a patient with adenocarcinoma of the kidney. J Orthomol Med I990;5:5-7.

28. Jackson JA, Riordan HD, Hunninghake RE, et al. High-dose intravenous vitamin C and long-time survival of a patient with cancer of the head of the pancreas. J Orthomol Med i995; I0:87-8.

29. Riordan $\mathrm{NH}$, Jackson JA, Riordan $\mathrm{HD}$. Intravenous vitamin $\mathrm{C}$ in a terminal cancer patient. J Orthomol Med ig96;II:80-2.

30. Riordan NH, Riordan HD, Casciari JJ. Clinical and experimental experiences with intravenous vitamin C. J Orthomol Med 2000;15:201-3.

3I. Ulchaker JC, Klein EA. Biology of metastasis and its clinical implications: renalcell cancer. World J Urol I996;I4:I75-8I.

32. Lokich J. Spontaneous regression of metastatic renal cancer. Case report and literature review. Am J Clin Oncol 1997;20:416-8.

33. Metts MC, Metts JC, Milito SJ, et al. Bladder cancer: a review of diagnosis and management. J Natl Med Assoc 2000;92:285-94.

34. Raghavan D. Chemotherapy and cystectomy for invasive transitional cell carcinoma of bladder. Urol Oncol 2003;21:468-74.

35. Winquist E, Kirchner TS, Segal R, et al. Neoadjuvant chemotherapy for transitiona cell carcinoma of the bladder: a systematic review and meta-analysis. J Urol 2004;171:56I-9.

36. Herr HW. Conservative management of muscle-infiltrating bladder cancer prospective experience. J Urol $1987 ; 138: 1162-3$.

37. Solsona E, Iborra I, Ricos JV, et al. Feasibility of transurethral resection for muscleinfiltrating carcinoma of the bladder: prospective study. JUrol I992;147:1513-5.

38. Buckman R, Sabbagh K. Magic of Medicine? An Investigation of Healing and Healers. Amherst, N.Y.: Prometheus Books, I995.

39. Kaptchuk TJ. Effect of interpretive bias on research evidence. $B M J$ 2003;326:I453-5.

40. Levine M, Conry-Cantilena C, Wang Y, et al. Vitamin C pharmacokinetics in healthy volunteers: evidence for a Recommended Dietary Allowance. Proc Natl Acad Sci U S A r996;93:3704-9.

4I. Levine $M$, Wang Y, Padayatty SJ, et al. A new recommended dietary allowance of vitamin C for healthy young women. Proc Natl Acad Sci U S A 2001;98:9842-6.

42. Bahlis NJ, McCafferty-Grad J, Jordan-McMurry I, et al. Feasibility and correlates of arsenic trioxide combined with ascorbic acid-mediated depletion of intracellular glutathione for the treatment of relapsed/refractory multiple myeloma. Clin Cancer Res 2002;8:3658-68.

43. Drisko JA, Chapman J, Hunter VJ. The use of antioxidants with first-line chemotherapy in two cases of ovarian cancer. J Am Coll Nutr 2003;22:118-23.

44. Drisko JA, Chapman J, Hunter VJ. The use of antioxidant therapies during chemotherapy. Gynecol Oncol 2003;88:434-9.
45. Food and Nutrition Board; Panel on Dietary Antioxidants and Related Compounds. Vitamin C. In: Anonymous Dietary Reference Intakes for Vitamin C, Vitamin E, Selenium, and Carotenoids. Washington DC: National Academy Press, 2000:95-185.

46. Levine M, Rumsey SC, Daruwala R, et al. Criteria and recommendations for vitamin C intake. JAMA I999;281:1415-23.

47. Rivers JM. Safety of high-level vitamin C ingestion. Ann N Y Acad Sci 1987;498: 445-54:445-454.

48. McAllister CJ, Scowden EB, Dewberry FL, et al. Renal failure secondary to massive infusion of vitamin C. JAMA I984;252:1684.

49. Wong K, Thomson C, Bailey RR, et al. Acute oxalate nephropathy after a massive intravenous dose of vitamin C. Aust N Z J Med I994;24:4IO-I.

50. Campbell A, Jack T. Acute reactions to mega ascorbic acid therapy in malignant disease. Scott Med J I979;24:I5I-3.

Correspondence to: Dr. Mark Levine, Molecular and Clinical Nutrition Section, Bldg. Io, Rm 4D52-MSC I372, National Institutes of Health, Bethesda MD 20892-I372;

MarkL@mail.nih.gov

\section{Editor's take}

- Intravenous administration of the maximum tolerated dose of vitamin C produces plasma levels 25 times that achieved when the same dose is administered orally. At high plasma concentrations vitamin $\mathrm{C}$ is toxic to some cancer cells but not to normal cells in vitro.

- Using the National Cancer Institute Best Case Series guidelines, the authors reviewed 3 cases of advanced cancer where patients had unexpectedly long survival times after receiving high-dose intravenous vitamin $\mathrm{C}$ therapy.

Implications for practice: In a setting of biological plausibility and clinical plausibility, further research into vitamin $C$ as a treatment for cancer is warranted.

\title{
Change of address
}

We require 6 to 8 weeks' notice to ensure uninterrupted service. Please send your current mailing label, new address and the effective date of change to:

\section{CMA Member Service Centre}

\author{
1867 Alta Vista Dr. \\ Ottawa ON K1G 3Y6
}

tel $888855-2555$ or

$613731-8610 \times 2307$

fax $613236-8864$

cmamsc@cma.ca

ASSOCIATION
MÉDICALE
CANADIENNE $\$ \begin{aligned} & \text { CANADIAN } \\ & \text { MEDICAL } \\ & \text { ASSOCIATION }\end{aligned}$

